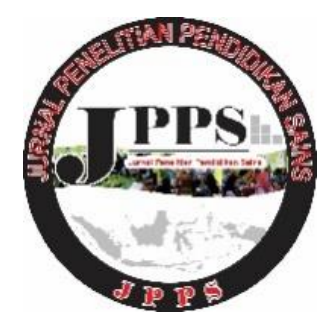

JPPS (Jurnal Penelitian Pendidikan Sains)

p-ISSN: 2089-1776

e-ISSN: 2549-1597

Volume 9, No. 1, November 2019

https://journal.unesa.ac.id/index.php/jpps/index

\title{
MODEL APPOSITE UNTUK MENINGKATKAN PENGUASAAN KONSEP FISIKA KINEMATIKA PADA MAHASISWA
}

\author{
SHB Prastowo*1, B Jatmiko², dan ZA Imam Supardi ${ }^{3}$ \\ ${ }^{*}$ Program Studi Pendidikan Fisika FKIP Universitas Jember,Indonesia \\ 2,3 Jurusan Fisika FMIPA Universitas Negeri Surabaya, Indonesia \\ Email:srihandono947@gmail.com
}

\begin{abstract}
Abstrak. Model Apposite merupakan suatu pengembangan model pembelajaran baru yang menunjukan interaksi antara guru dan siswa berdasarkan pada kemampuan skemata serta respon dari siswa. Model ini menekankan interaksi guru dan siswa dalam pembelajaran dengan menggunakan pendekatan kontekstual yang diharapkan mampu mengontrol proses kognitif siswa secara berkesinambungan.Penguasaan konsep Fisika merupakan kemampuan mahasiswa dalam menguasai konsep serta aplikasinya dalammenyelesaikan permasalahan.Kinematika merupakan materi Fisika yang membahas tentanggerk suatu benda tanpa memperhitungkan penyebab benda tersebut bergerak. Terdapat 7 tahapan dalam menggunakan model Apposite pada pembelajaran Fisika melalui pendekatan kontekstual; Invitasi, Eksplorasi, Elaborasi, Penjelasan dan solusi, Pengambilan tindakan dan evaluasi,serta refleksi.diri. Desain penelitian yang digunakan dalam penelitian ini menggunakan pre tes post tes one group desain dengan responden dalam aplikasi model ini adalah mahasiswa semester 1 Prodi Fsika FKIP universitas jember. Dari hasil penelitian yang dilakukan untuk mengetahui penguasaan konsep mahasiswa didapatkan bahwa terdapat peningkatan penguasaan konsep mahasiswa pada materi Kinematika dengan kategori sangat baik dengan tingkat kefektifan dalam kategori cukup efektif.
\end{abstract}

Keywords : Model Apposite, Penguasaan konsep, Kinematika. 


\section{PENDAHULUAN}

Upaya siswa dalam mempelajari Fisika sering menemui hambatan. Dari wawancara dengan mahasiswa mengatakan bahwa Fisika dianggap sebagai pelajaran yang sulit dipahami. Kemampuan mahasiswa yang rendah dalam pelajaran Fisika sangat terkait dengan penguasaan konsep yang diajarkan. Mengembangkan penguasaan konsep sangat bermanfaat bagi siswa dan mahasiswa bukan hanya selama proses pembelajaran namun juga diperlukan untuk menyelesaikan masalah-masalah dalam kehidupan sehari-hari. Ruseffendi (2006) menuliskan "orang yang kreatif bukan hanya bermanfaat untuk dirinya sendiri tetapi juga membantu orang lain dalam interaksi sosial" Untuk menghadapi masa depan yang selalu berubah, penuh tantangan dan persaingan yang semakin ketat memerlukan keluaran pendidikan yang tidak hanya terampil dalam satu bidang ditekuni, tetapi umum dalam penelitian ini adalah : Bagaimanakah juga kreatif dalam mengembangkan bidang tersebut. kelayakan model pembelajaran APPOSITE untuk Oleh karena itu, perlu diaplikasikan dalam setiap mata meningkatkan penguasaan konsep Kinematika dalam kuliah di perguruan tinggi termasuk dalam mata kuliah pembelajaran fisika?

Fisika. Salah satu faktor yang membuat Fisika

Kemudian secara umum tujuan penelitian ini dianggap sulit dan sering menimbulkan kurangnya adalah untuk mendiskripsikan kelayakan model penguasaan konsep adalah Fisika memiliki kajian yang dalam meningkatkan penguasaan konsep Fisika komplek baik abstrak maupun real yang memerlukan materi Kenematika.

penguasaan konsep dan matematis. Sebagai contoh persamaan kecepatan $\bar{V}_{t}=\bar{V}_{0}+a t$ dan persamaan posisi $\overline{X_{t}}=\overline{X_{0}}+\overline{V_{0}} t+1 / 2 a t^{2}$ dari kedua persamaan tersebut anggapan apa yang tersembunyi yang seharusnya digunakan? Anggapan yang digunakan adalah percepatan harus selalu tetap. Jika percepatan tidak tetap menggunakan hubungan yang lebih umum: $\bar{V}-\overline{V_{0}}=\int a d t \operatorname{dan} \overline{X_{t}}-\overline{X_{0}}=\int V d t$.

Strategi pembelajaran menggunakan model pembelajaran APPOSITE dengan pendekatan kontekstual disertai instruksi bertingkat (step instruction) dapat dijadikan sebagai salah satu alternatif dalam pembelajaran. Strategi ini dilakukan untuk meningkatkan penguasaan konsep dan mengembangkan kemampuan berpikir kreatif mahasiswa.

Hasil observasi tersebut secara umum permasalahan dapat digambarkan dalam alur berikut :

Mendasari pendapat Corpuz (2006), Sands (2005), Rimoldini \& Singh (2005), Jackson et al. (2008), dan Suryadi (2010), nampak bahwa suatu pembelajaran dilakukan melalui tiga fase penelitian yang berurutan .Fase pertama penelitian mengidentifikasi penguasaan konsep awal yang terjadi dan kemampuan berpikir yang telah dimiliki siswa dengan menggunakan pretes. Penguasaan konsep awal yang ada dijadikan acuan dalam merancang instruksi bertingkat (stepinstruction) dalam mengembangkan materi instruksional yang berupa model pembelajaran dengan melihat bagaimana karakteristik model, kelayakan model serta validitas model yang diukur dari hasil validasi pakar Fase kedua penelitian membantu siswa saat mengkonstruksi dan merekonstruksi pemahamannya melalui pemanfaatan rancangan instruksi bertingkat (step instruction) dalam materi instruksional. Pada fase ini melakukan uji coba dan pemantapan model pembelajaran yang selanjutnya proses dan tingkat pemanfaatan step instruction tersebut dijadikan acuan dalam menyempurnakan rancangan materi instruksional.Fase ketiga penelitian dilakukan mengembangkan dan sekaligus menggunakan desain model pembelajaran untuk mengajarkan materi instruksional tersebut, untuk melihat bagaimana kepraktisan dan keefektifan model. Kepraktisan model diukur dari keterlaksanaan perangkat 
pembelajaran dengan menggunakan model instruksi 1.Hasil keterlaksanaan Pembelajaran

bertingkat (step instruction), serta cara mengatasi

Keterlaksanaan model pembelajaran Apposite kendala-kendala yang terjadi. Keefektifan model dapat yang telah tervalidasi selanjutnya diaplikasikan dilihat dari bagaimana peningkatan penguasaan konsep dengan responden mahasiswa dengan materi konsep mahasiswa yang terjadi. Alur pelaksanaan Model Kinematika. Rangkuman hasil pengamatan APPOSITE dalam pembelajaran Fisika ada 7 tahapan keterlaksanaan pembelajaran dapat ditunjukan pada yang dapat dilakukan: 1.Invitasi 2.Eksplorasi 3. tabel berikut:

Elaborasi 4.Penjelasan dan solusi 5. Pengambilan tindakan 6.Pengujian dan evaluasi dan 7. Refleksi diri.

\section{METODE \\ Desain penelitian sesuai dengan} permasalahan dalam penelitian ini terdiri atas tiga fase: Pertama fase pengembangan model pembelajaran, Kedua fase uji coba model pembelajaran dan ketiga fase implementasi pembelajaran. fase pertama merupakan penelitian kualitatif. secara umum memilih pengambilan subjek secara purposive sampling, yakni memilih subjek sesuai dengan tujuan yang akan dicapai dan menghasilkan pemahaman terbaik tentang apa yang sedang diteliti. . Fase kedua pada penelitian ini peneliti merancang model pembelajaran dengan komponen: 1) Tujuan 2) Dasar teori yang mendukung 3) Sintaks model dan 4) Lingkungan belajar yang merupakan kegiatan pembelajaran dan dampak instruksional yang terjadi untuk mendukung implementasi model pembelajaran yang dikembangkan

Dalam penelitian ini menggunakan desain one group pretes-posttest, yakni satu kelompok siswa dikenai perlakuan dan variabel dependen diukur untuk menilai pengaruh dari pemberian perlakuan tersebut. (Fraenkel,et.al,2012).

Diagram dari desain one group pretes-posttest ditunjukan pada gambar 3.2.

\begin{tabular}{cccc}
\hline 0 & $\mathrm{X}$ & 0 & \\
Pretest & Treatment & & Postest \\
\hline
\end{tabular}

Gambar 3.2 Desain One-Group Pretest-Posttest

\section{Keterangan :}

$\mathrm{X}$ : pembelajaran dengan model yang dikembangkan (model pembelajaran APPOSITE )

$\mathrm{O}$ : hasil belajar materi kinematika

Fase ketiga merupakan implementasi pengembangan model yang lebih luas dengan menggunakan metode eksperimen the randomized pretest-posttest control group design (Fraenkel, et.al, 2012:272). Subjek penelitian adalah mahasiswa Jurusan pendidikan Fisika PMIPA FKIP Unej

\section{Hasil dan Diskusi}

Tabel:1 Keterlaksanaan Pembelajaran Kajian Materi Gerak (Kinematika) Pertemuan I

\begin{tabular}{lcl}
\hline \multirow{2}{*}{ Tahapan } & \multicolumn{2}{c}{ Pertemuan I } \\
\cline { 2 - 3 } & $\begin{array}{c}\text { Rerata } \\
\text { skor }\end{array}$ & kriteria \\
\hline Invitasi & 3.0 & Baik \\
\hline Eksplorasi & 3.0 & Baik \\
\hline Elaborasi & 3.25 & $\begin{array}{l}\text { Sangat } \\
\text { baik }\end{array}$ \\
\hline $\begin{array}{l}\text { Penjelasan dan } \\
\text { solusi }\end{array}$ & 3.30 & $\begin{array}{l}\text { Sangat } \\
\text { baik }\end{array}$ \\
\hline $\begin{array}{l}\text { Pengambilan } \\
\text { tindakan }\end{array}$ & 3.17 & baik \\
\hline $\begin{array}{l}\text { Evaluasi } \\
\text { Refleksi }\end{array}$ & 3.30 & $\begin{array}{l}\text { Sangat } \\
\text { baik }\end{array}$ \\
\hline
\end{tabular}

Tabel:2 Keterlaksanaan Pembelajaran Kajian Materi Gerak (Kinematika) Pertemuan II

\begin{tabular}{lcl}
\hline \multirow{2}{*}{ Tahapan } & \multicolumn{2}{c}{ Pertemuan II } \\
\cline { 2 - 3 } & $\begin{array}{r}\text { Rerata } \\
\text { skor }\end{array}$ & kriteria \\
\hline Invitasi & 3.0 & Baik \\
\hline Eksplorasi & 3.30 & $\begin{array}{l}\text { Sangat } \\
\text { baik }\end{array}$ \\
\hline Elaborasi & 3.30 & $\begin{array}{l}\text { Sangat } \\
\text { baik }\end{array}$ \\
\hline $\begin{array}{l}\text { Penjelasan } \\
\text { dan solusi }\end{array}$ & 3.50 & $\begin{array}{l}\text { Sangat } \\
\text { baik }\end{array}$ \\
\hline $\begin{array}{l}\text { Pengambilan } \\
\text { tindakan }\end{array}$ & 3.30 & $\begin{array}{l}\text { Sangat } \\
\text { baik }\end{array}$ \\
\hline Evaluasi & 2.80 & Baik \\
\hline Refleksi & 3.33 & $\begin{array}{l}\text { Sangat } \\
\text { baik }\end{array}$ \\
\hline
\end{tabular}

Tabel:3 Keterlaksanaan Pembelajaran Kajian Materi Gerak (Kinematika) Pertemuan III

\begin{tabular}{lcc}
\hline \multirow{2}{*}{ Tahapan } & \multicolumn{2}{c}{ Pertemuan III } \\
\cline { 2 - 3 } & $\begin{array}{c}\text { Rerata } \\
\text { skor }\end{array}$ & kriteria \\
\hline Invitasi & 3.17 & Baik \\
\hline
\end{tabular}




\begin{tabular}{lcc}
\hline \multirow{2}{*}{ Tahapan } & \multicolumn{2}{c}{ Pertemuan III } \\
\cline { 2 - 3 } & $\begin{array}{c}\text { Rerata } \\
\text { skor }\end{array}$ & kriteria \\
\hline Eksplorasi & 3.50 & $\begin{array}{c}\text { Sangat } \\
\text { baik }\end{array}$ \\
\hline Elaborasi & 3.50 & $\begin{array}{c}\text { Sangat } \\
\text { baik }\end{array}$ \\
\hline $\begin{array}{l}\text { Penjelasan } \\
\text { dan solusi }\end{array}$ & 3.50 & $\begin{array}{c}\text { Sangat } \\
\text { baik }\end{array}$ \\
\hline $\begin{array}{l}\text { Pengambilan } \\
\text { tindakan }\end{array}$ & 3.33 & $\begin{array}{c}\text { Sangat } \\
\text { baik }\end{array}$ \\
\hline Evaluasi & 3.00 & Baik \\
\hline Refleksi & 3.50 & $\begin{array}{c}\text { Sangat } \\
\text { baik }\end{array}$ \\
\hline
\end{tabular}

Tabel:4 Keterlaksanaan Pembelajaran Kajian Materi Gerak (Kinematika) Pertemuan IV

\begin{tabular}{lcc}
\hline \multirow{2}{*}{ Tahapan } & \multicolumn{2}{c}{ Pertemuan IV } \\
\cline { 2 - 3 } & $\begin{array}{c}\text { Rerata } \\
\text { skor }\end{array}$ & Kriteria \\
\hline Invitasi & 3.0 & Baik \\
\hline Eksplorasi & 3.33 & $\begin{array}{c}\text { Sangat } \\
\text { baik }\end{array}$ \\
\hline Elaborasi & 3.50 & $\begin{array}{c}\text { Sangat } \\
\text { baik }\end{array}$ \\
\hline $\begin{array}{l}\text { Penjelasan } \\
\text { dan solusi }\end{array}$ & 3.50 & $\begin{array}{c}\text { Sangat } \\
\text { baik }\end{array}$ \\
\hline $\begin{array}{l}\text { Pengambilan } \\
\text { tindakan }\end{array}$ & 3.33 & $\begin{array}{c}\text { Sangat } \\
\text { baik }\end{array}$ \\
\hline Evaluasi & 3.33 & $\begin{array}{c}\text { Sangat } \\
\text { baik }\end{array}$ \\
\hline Refleksi & 3.33 & $\begin{array}{c}\text { Sangat } \\
\text { baik }\end{array}$ \\
\hline
\end{tabular}

Berdasarkan hasil analisis data yang ditunjukan Tabel 1 sampai dengan 4 dapat dilihat bahwa seluruh langkah pembelajaran dapat dilaksanakan dengan baik oleh dosen.

\section{Hasil Penguasaan Konsep Kinematika}

Untuk mengetahui penguasaan konsep mahasiswa serta efektivitas pembelajaran dilakukan post tes pada akhir pembelajaran yang hasilnya dapat ditunjukan dalam tabel5 berikut:

Tabel :5 : Hasil penguasaan konsep dan Uji efektivitas materi Kinematika

\begin{tabular}{cccccc}
\hline No. & $\begin{array}{c}\text { PRE } \\
\text { TES I } \\
(\mathbf{x} 1)\end{array}$ & $\begin{array}{c}\text { POST } \\
\text { TES I } \\
(\mathbf{x} 2)\end{array}$ & $\boldsymbol{\Delta} \mathbf{X}$ & $\begin{array}{c}\text { N- } \\
\text { GAIN }\end{array}$ & Kriteria \\
\hline 1 & 45 & 78 & 33 & .60 & sedang \\
\hline 2 & 60 & 82 & 22 & .55 & sedang \\
\hline 3 & 42 & 73 & 31 & .53 & sedang \\
\hline 4 & 63 & 85 & 22 & .59 & sedang \\
\hline 5 & 51 & 80 & 29 & .59 & sedang \\
\hline 6 & 53 & 74 & 21 & .45 & sedang \\
\hline 7 & 48 & 76 & 28 & .53 & sedang \\
\hline 8 & 48 & 74 & 26 & .50 & sedang \\
\hline 9 & 58 & 84 & 26 & .62 & sedang \\
\hline 10 & 60 & 80 & 20 & .50 & sedang \\
\hline 11 & 54 & 74 & 20 & .43 & sedang \\
\hline 12 & 57 & 80 & 23 & .53 & Sedang \\
\hline 13 & 55 & 77 & 22 & .48 & Sedang \\
\hline 14 & 51 & 78 & 27 & .55 & Sedang \\
\hline 15 & 63 & 80 & 17 & .45 & Sedang \\
\hline 16 & 68 & 86 & 18 & .56 & Sedang \\
\hline 17 & 52 & 85 & 33 & .68 & Sedang \\
\hline 18 & 50 & 81 & 31 & .62 & Sedang \\
\hline 19 & 52 & 82 & 30 & .62 & Sedang \\
\hline 20 & 40 & 72 & 32 & .53 & Sedang \\
\hline Jml & 1070 & 1581 & 511 & & \\
\hline Rerata & 53.50 & 79.05 & 25.55 & .55 & Sedang \\
\hline & & & & & \\
\hline
\end{tabular}

Mendasari hasil uji efektivitas pada penguasaan konsep mahasiswa materi kinematika termasuk dalam kategori sedang, namun terjadi peningkatan penguasaan konsep yang cukup tinggi dari hasil pre tes dan post tes .

\section{B. Diskusi}

Pada keterlaksanaan pembelajaran menunjukan bahwa secara umum tahap ke tujuh model pembelajaran APPOSITE dapat terlaksana dengan baik. Mahasiswa dengan sangat baik berusaha untuk melakukan refleksi diri dari hasil belajar yang telah dilakukan. Mulai pertemuan awal hingga pertemuan ketujuh dengan sangat baik selalu melakukan refeksi hasil pembelajaran bahkan pada akhir pertemuan delapan dan sembilan mengalami peningkatan. Keadaan ini menunjukan bahwa model APPOSITE berhasil dalam melatih mahasiswa membentuk sikap spritual yang lebih baik dan terbiasa selalu melakukan refleksi diri dari apa yang telah dilkukan. menunjukan bahwa secara umum tahap ke tujuh model pembelajaran APPOSITE dapat terlaksana dengan baik. Mahasiswa dengan sangat baik berusaha untuk melakukan refleksi diri dari hasil belajar yang telah dilakukan. Mulai pertemuan awal hingga pertemuan ketujuh dengan sangat baik selalu melakukan refeksi hasil pembelajaran, bahkan pada akhir pertemuan mengalami peningkatan. Keadaan ini menunjukan bahwa model APPOSITE berhasil dalam melatih mahasiswa membentuk sikap spritual 
yang lebih baik dan terbiasa selalu melakukan refleksi diri dari apa yang telah dilkukan. Hal ini sesuai dengan pendapat Moreno(2010) bahwa siswa/mahasiswa harus mampu melakukan evaluasi diri dari hasil pembelajaran yang telah dilakukan.

Dampak instruksional dan dampak pengiring model pembelajaran APPOSITE adalah meningkatkan penguasaan konsep mahasiswa yang menunjukan bahwa pada sintaks model pembelajaran APPOSITE telah terlaksana dengan baik yang berdampak signifikan pada peningkatan penguasaan konsep Fisika tentang kinematika yang dapat dilihat dengan adanyakenaikan nilai pre tes dan post tes dengan efektivitas dalam kategori sedang. Walaupun dalam kategori sedang namun kenaikan penguasaan konsep cukup tinggi dari hasil rata rata pre tes 53.5 meningkat menjadi 79.05 pada rata-rata post tes.

\section{KESIMPULAN}

Keterlaksanaan perangkat pembelajaran menggunakan model pembelajaran APPOSITE dapat berjalan dengan baik, yang ditunjukan dengan adanya peningkatan kegiatan siswa dalam tiap tahap dan efektivitas model pembelajaran APPOSITE yang dikembangkan termasuk dalam kategori efektif karena dapat memberikan dampak terhadap peningkatan penguasaan konsep mahasiswa.

\section{DAFTAR PUSTAKA}

A.Hakim,Liliasari, ASetiawan,\& G,A,P. Saptowati (2017), Interactive Multimedia Thermodynamics to Improve creative Thinking Skill of Physics Prospective Teachers,Jurnal Pendidikan Fisika Indonesia, vol 13(1)

Alicia R.Allbaugh (2003), Desertasi,The ProblemContext Dependence of StudentAplication of Newton's Second Law, Kansas State University, Manhattan

Al-Choo Ong \& Gary D Borich, (2006), Teaching Srategies that Promote Thinking Models and Curricullum Approaches, Singapore, McGrawHill

Aldridge,J.M.,Fraser,B.J.,Taylor,P.C.,dan Chen,C.C 2000,Constructivist Learning Environments in a cross-National Study in Taiwan and Australia, International Journal of Science Education,22(1),pp. 37-55

A.Hakim,Liliasari, ASetiawan,\& G,A,P. Saptowati (2017), Interactive Multimedia Thermodynamics to Improve creative Thinking
Skill of Physics Prospective Teachers,Jurnal Pendidikan Fisika Indonesia, vol 13(1)

Alicia R.Allbaugh (2003), Desertasi,The ProblemContext Dependence of StudentAplication of Newton's Second Law, Kansas State University, Manhattan

Al-Choo Ong \& Gary D Borich, (2006), Teaching Srategies that Promote Thinking Models and Curricullum Approaches, Singapore, McGraw-Hill

Aldridge,J.M.,Fraser,B.J.,Taylor,P.C.,dan Chen,C.C 2000,Constructivist Learning Environments in a cross-National Study in Taiwan and Australia, International Journal of Science Education,22(1),pp. 37-55

Anita Woofolk,dkk (2008), Psychology in education, England Pearson Education Limited.

Arends, R.I. 2012 Learning to Teach, $9^{\text {th }}$ Edition, New York: McGraw-Hill Coimpanies,Inc

Forte, A. (2015). The new information literate open collaboration and information production in schools. International Journal ComputerSupported Collaborative Learning, 10 (1), 35-51.

Miller, K., Lasry, N., Chu, K., \& Mazur., E. (2013). Role of physics lecture demonstrations in conceptual learning. Physical Review Special Topics - Physics Education Research, 9, 020113

Miller, K., Schell, J., Ho, A., Lukoff, B., \& Mazur, E. (2015). Response switching and selfefficacy in peer instruction classrooms. Physical Review Special Topics - Physics Education Research, 11, 010104

Moreno, R. (2010). Educational psychology. New York: Jhon Wiley \& Sonc, Inc.

Prastowo SHB, Jatmiko B,Supardi I ZA,(2017),Apposite Model to Improve Mastery of Kinetic Motion Concept for Physics Education Student, The International Journal of SocialScience and Humanities Invention DOI 10.16535/hjsski/4i8.01

Puspitasari lila,In'am A, \& Saifudin Moh,(2019) Analysis of Students Creative Thinking in Solving Arithmetic Problem,International Electronic Journal Of Mathematics Education,vol14,No1. 